\title{
Finansal Piyasalar Arasındaki Uzun Dönem Çapraz Korelasyon İlişkisi: Türkiye ile BRICS Ülkeleri Örneği
}

\author{
Havva Gültekin a,b, Ayşegül İşcanoğlu Çekiç c
}

Özet

Çalışma, Türkiye ile BRICS ülkelerinin oynaklıkları (volatiliteleri) arasında çapraz korelasyonların varlığını, diğer bir deyişle oynaklıkların yayılma etkisini 3 Şubat 2012-1 Haziran 2018 döneminde araştırmayı amaçlamaktadır. Çalışma, literatüre BRICS ülkelerinin oynaklıklarının Türkiye finansal piyasalarındaki oynaklıklar üzerindeki etkisini MF-X-DMA yöntemi kullanarak tespit etmeye çalışması açısından katkıda bulunmaktadır. Amprik sonuçlar, Türkiye-Brezilya oynaklıkları, Türkiye-Rusya oynaklıkları, TürkiyeHindistan oynaklıkları, Türkiye-Çin oynaklıkları ve Türkiye-Güney Afrika oynaklıkları arasındaki çapraz korelasyonların güçlü çoklu fraktal yapıda olduğunu ve piyasalardaki küçük ve büyük şokların etkisinin çapraz korelasyonlarda uzun dönem kalıcılık gösterdiğini ortaya çıkarmıştır.
Anahtar Kelimeler

Çapraz Korelasyonlar

Fraktal

Uzun Dönem İlişki

BRICS-T

Makale Hakkında

Geliş Tarihi: 24.09.2018

Kabul Tarihi: 15.11.2019

Doi: $10.18026 /$ cbayarsos.664400

\section{Long Term Cross Correlations Between Financial Markets: An Application to Turkey and BRICS Countries}

\begin{abstract}
In the study the cross correlations between Turkey stock market volatility and the stock market volatilities of BRICS countries are investigated in the period from February 3, 2012 to June 1, 2018. This study contributes to the literature by employing the MF-X-DMA method to analyse the effect of stock market volatilities of the BRICS countries to the Turkish stock market. Emprical results show that cross correlations between volatilities of Turkey-Brazil, volatilities of Turkey-Russia, volatilities of Turkey-India, volatilities of TurkeyChina and volatilities of Turkey-South Africa have strong multifractal features. Moreover, the effects of small and large shocks in cross correlations are persistant in the long run.
\end{abstract}

Keywords

Cross Correlations

Fractal

Long Term Dependence

BRICS-T

About Article

Received: 24.09.2018

Accepted: 15.11.2019

Doi: 10.18026/cbayarsos.664400

a İletişim Yazarı: havvagultekin@trakya.edu.tr

b Arş. Gör., Trakya Üniversitesi, İktisadi ve İdari Bilimler Fakültesi, Ekonometri Bölümü, Edirne/Türkiye, 0000-0002-3157-4635.

c Dr. Öğr. Üyesi, Trakya Üniversitesi, İktisadi ve İdari Bilimler Fakültesi, Ekonometri Bölümü, Edirne/Türkiye, 0000-0003-0692-7870. 


\section{Giriş}

Son yıllarda küreselleşme hareketleri ile birlikte, dünya ekonomileri arasındaki mevcut ilişki farklı boyutlar kazanmıştır. Bunlardan, korumacı politikalara dayanan engellerin kaldırılması, ülkelerin para ve sermaye piyasalarında liberalleşme sürecinin artması şeklindeki unsurlar oldukça önem arz etmektedir. Ekonomiler arasındaki engeller ortadan kalktıkça piyasalar birbirleriyle daha yakın ve daha yoğun bir ilişki kurmaktadır. Bu durum ekonomilere yeni fırsatlar sunarken, diğer yandan ise ekonomileri belirli risklere de maruz bırakmaktadır (Vuran ve Türkay, 2017:1). Örneğin; küresel piyasaların ortak eğilimler içine girmesiyle birlikte, ülke borsaları arasındaki korelasyonlar artmakta ve bunun sonucunda da uluslararası çeşitlendirmeden sağlanacak faydalar azalabilmektedir (Gilmore ve McManus, 2002:69-70). Diğer bir deyişle; hisse senedi piyasaları arasındaki korelasyon katsayısının düşük olması hisse senedi piyasalarının büyük ölçüde birbirinden bağımsız olduğunun bir göstergesidir ve çeşitlendirmenin faydasını ortaya koymaktadır. $\mathrm{Bu}$ nedenle, finansal kestirimlerin doğruluğunu artırmak, belli yatırım risklerinden kaçınmak amacıyla piyasalar arası ilişkilerin incelenmesi hem yatırımcılar hem de akademisyenler açısından oldukça önemlidir.

Literatürde piyasalar arası bu korelasyonlar, piyasalar arası çapraz korelasyonlar olarak adlandırılmakta ve ticari ve finansal bakımdan etkileşimin güçlü olduğu ülkelerin herhangi birinde meydana gelebilecek bir şokun etkisinin diğer ülkelere de yansıması olarak tanımlanabilmektedir (Polat ve Gemici, 2017:394). Çapraz korelasyon fonksiyonları, otokorelasyon fonksiyonları ile birlikte doğal sistemlerin dinamiklerini anlamak için yaygın olarak kullanılmaktadır. Fakat yapılan çalışmalar, bu tekniklerin birçoğunun yalnızca durağanlık sağlandığında kullanılması gerektiğini göstermiştir. Diğer taraftan, birçok fiziksel, biyolojik, hidrolojik ve sosyal sistem zaman serisinin durağan olmadığı ve uzun dönem güçkuralı korelasyonlar sergilediği önemli bir gerçektir (Podobnik vd., 2009:243).

Finansal piyasalar genel yapıları itibarıyla durağan değildir ve piyasalar arası mevcut çapraz korelasyonların istatistiksel özelliklerini incelemek uygulamada oldukça zordur. Bu çalışmada, Mandelbrot $(1972,1974,1977)$ tarafından önerilen fraktal teoriye dayanan MF-XDMA analizi kullanılarak Türk finansal piyasası ile BRICS ülkelerinin MSCI ETF endekslerine ait oynaklıkları arasındaki uzun dönem kuvvet-kuralı çapraz korelasyonların varlığı araştırılmıştır. MSCI endeksleri, küresel sermayenin ve uluslararası yatırımların belirlenmesinde önemli birer referans ölçek olmaları sebebiyle uluslararası yatırımcılar açısından önem taşımaktadır. Bu bağlamda çalışma, yöntemsel olarak güncel olmasının yanı sıra, BRICS ülkelerinin, Türkiye ile ilişkisinin belirlenmesi açısından da literatüre katkıda bulunmaktadir.

Çalışmanın ikinci bölümünde BRICS ülkeleri hakkında genel bilgi ve BRICS ülkeleri ile Türkiye arasındaki ilişkileri inceleyen çalışmalara ait literatür özeti verilmiştir. Çalışmanın üçüncü bölümünde, MF-X-DMA yöntemi tanıtılmıştır. Çalışmanın dördüncü bölümünde veriye ait temel istatistikler ve analiz sonuçları sunulmuştur. Çalışmanın beşinci bölümünde ise bulgular sunulup çalışma sonlandırılmıştır.

\section{BRICS Ülkeleri ve Literatür Özeti}

Son yıllarda siyasal gelişmelerin yanı sıra ekonomik düzende de değişimin yaşandığ dünyada, gelişmiş ve gelişmekte olan ülkelerin göstergelerine bakıldığında küresel piyasada 
dengelerin değiştiği görülmektedir. Yoğun rekabet ortamında dünya ülkelerinin gerek üst seviyelere yükselmek gerek değişen koşullarda çıkarlarını korumak amacıyla farklı politikalar uyguladıkları görülmüştür.

Özellikle son yıllarda ekonomisi hızla büyüyen, yabancı yatırımların büyük çoğunluğunu çekebilen ve küresel dünyayı etkileme gücü hızla artan ekonomiler farklı biçimlerde gruplandırılmaya başlamıştır. Bunlar arasında BRICS ülkeleri olarak adlandırılan bir grup düşük üretim maliyeti, doğrudan yabancı sermaye yatırımlarını çekme ve ihracat döviz rezervleri ve millî gelirini hızla artırması ve ekonomik krizlerden daha az etkilenmesi bakımından dikkat çekmiştir (Ağır ve Yıldırım, 2015; Kılıç ve Dilber, 2017).

BRIC ismi, ilk olarak 2001 yılında ekonomist Jim O'Neill tarafından ortaya atılmış ve dünya ekonomisinde en hızlı gelişen piyasalar olarak kabul edilmiştir. Bu ülkelere 24 Aralık 2010 tarihinde Güney Afrika'nın da eklenmesiyle BRICS ülkeleri adını almıştır (Ağır ve Yıldırım, 2015:41).

Goldman Sachs, 2001 yılı raporunda, BRIC ülkelerinin 2050 yılına kadar dünyanın en büyük ekonomileri olacağı belirtilmiş ve bu ülkelerin ortak özellikleri şu şekilde sıralanmıştır;

a. Bu ekonomiler son dönemde sanayileşme yolunda hızla ilerlemiş ve hızla büyüyen ekonomilerdir.

b. Kendi bölge ve küresel konular üzerinde ciddi oranda söz sahibidirler.

c. Tamamı G20 üyesidir.

d. Bu ülkeler dünya nüfusunun neredeyse $\% 40$ 'tan fazlasını ve dünya ekonomisinin yaklaşık yüzde 20'sini oluşturmaktadırlar.

Yine bu rapora göre dünyanın en büyük ekonomisinin Çin olması beklenirken, üçüncü büyük ekonomisinin Hindistan ve dördüncü büyük ekonominin Brezilya, altıncı büyük ekonomisinin Rusya olacağ öngörülmektedir.

Şu anda BRICS ülkeleri ile ekonomik, politik, kültürel ve coğrafya açısından heterojen olan Meksika, Türkiye, Endonezya ve Güney Kore gibi bazı ülkeler, BRICS'e aday ülkeler olarak gösterilmektedir (Sosa ve Cabello, 2015). BRICS ülkeleri ile Türkiye birbirinden uzak coğrafyada olmalarına karşı, iktisadi ve siyasi alanlarda her geçen gün birbirine yaklaşmaktadırlar.

BRIC ülkelerinin büyümesi, yatırım fonları, bireysel yatırımcılar ve finansal kurumları içeren çeşitli yatırım topluluklarını çekmiştir.

$\mathrm{Bu}$ alanda BRICS ülkelerine ait borsalar üzerine yapılan çalışmalar son yıllarda hız kazanmıştır. Bu çalışmalar, birçok yönden ele alınabilmektedir. Örneğin; Zhao (2010), Chkili ve Nguyen (2014), Sui ve Sun (2016), çalışmalarında BRICS ülkelerine ait finansal piyasalar ile döviz kuru piyasaları arasındaki ilişkileri analiz etmişlerdir. Diğer taraftan, Ono (2011), Ma vd. (2013), Kang vd. (2016), Boubaker ve Raza (2017), vb. çalışmalarda BRICS ülkelerine ait finansal piyasalar ile petrol fiyatları arasındaki etkileşimler araştırılmıştır. Aşağıda da konumuz ile ilgili olarak BRICS ülkelerine ait finansal piyasalar ile diğer ülke piyasaları arasındaki ilişkilerin ve etkileşimlerin analizine dair güncel çalışmalar listelenmiştir.

Bozoklu ve Saydam (2010), BRIC ülkeleri ile Türkiye sermaye piyasalarının entegre olup olmadıklarını, 2005-2010 arası günlük verileri kullanarak eş bütünleşme testleri ile test etmişler ve analiz sonucunda BRIC ülkeleri ve Türkiye sermaye piyasalarının entegre olduğu ve uzun vadede kâr imkânının olmadığı sonucuna varmışlardır. 
Evlimoğlu ve Çondur (2012) çalışmalarında, Türkiye ile Brezilya, Çin, Hindistan, Rusya, Japonya, Almanya ve Amerika borsaları arasındaki kısa dönemli ilişkileri, mortgage krizi öncesi (05/01/2004- 31/07/2007) ve mortgage krizi sonrası (01/08/2007-01/01/2010) dönemini kapsayan günlük verileri kullanarak incelemişlerdir. VAR modelinin kullanıldığı çalışmada, Mortgage krizi sonrası dönemde BIST ile diğer borsalar arasındaki bağlantıların arttığı tespit edilmiştir.

Akal (2013) çalışmasında, yükselen borsalardan Brezilya, Meksika, Hindistan, Çin, Güney Kore, Endonezya, Rusya ile BIST100 arasındaki kısa ve uzun dönem ikili ilişkileri dikkate almıştır. Ek olarak çalışmaya, gelişmiş piyasalardan Kanadaya ait GSPTSE borsasını da eklemiştir. Çalışmada, 01.2000-12.2012 dönemine ait aylık veriler kullanılmış ve nedensellik ilişkileri, VAR ve Granger Wald testi ile analiz edilmiştir. Analiz sonucunda ele alınan borsaların, uzun ve kısa dönemde BIST100 ile aynı yönlü ilişkili olduğu tespit edilmiştir.

Zhang vd. (2013), G7 ve BRICS ülkelerine ait hisse senedi ve tahvil piyasaları arasındaki oynaklık yayılmalarını, Hafner ve Herwartz tarafından geliştirilen varyans nedensellik testini kullanarak incelemişlerdir. Çalışmada, 30 Aralık 1988- 7 Aralık 2012 dönemi dikkate alınmış ve analizlerde günlük veri kullanılmıştır. Çalışmanın bulgularına göre, tüm gelişmiş ülkelerde, tahvil ve hisse senedi piyasaları arasında tek yönlü ya da iki yönlü yayılma etkisinin olduğu \%1 anlamlılık düzeyinde gösterilmiştir. Fakat gelişmekte olan piyasalardan, Rusya'nın hisse senedi ve tahvil piyasaları arasında her iki yönde de yayılma etkisinin zayıf olduğu \%1 anlamlılık düzeyinde tespit edilmiştir.

Zhang vd. (2013), gelişmekte olan BRICS, Amerika and Avrupa borsaları arasındaki dinamik korelasyon yapısını belirlemek amacıyla 1 Ocak 2000 - 31 Mart 2012 dönemine ait günlük getiri serilerini dikkate almışlardır. Analizlerde, Amerikan borsasına ait S\&P 500 ve Avrupa borsasına ait MSCI Avrupa gösterge endeklerini kullanmışlar ve DCC (Dinamik Koşullu Korelasyon) yöntemi ile ilişkileri analiz etmişlerdir. Analiz sonuçları, finansal kriz sonrası borsalar arası korelasyonların değiştiğini ortaya koymuştur.

Benli Keskin (2014), Türkiye hisse senedi piyasasının gelişmekte olan ülkelere (Latin Amerika ülkelerinden Brezilya, Şili, Kolombiya, Meksika, Peru; Avrupa Orta Doğu ve Afrika ülkelerinden Çek Cumhuriyeti, Mısır, Yunanistan, Macaristan, Polonya, Rusya, Güney Afrika; Asya ülkelerinden Çin, Hindistan, Endonezya, Kore, Malezya, Filipinler, Tayvan ve Tayland) ait hisse senedi piyasaları ile uzun dönemli ilişkisini araştırmıştır. Çalışmada, 30 Aralık 1994 ile 30 Eylül 2013 dönemi dikkate alınmış ve ilişkiler Johansen eşbütünleşme testi ile analiz edilmiştir. Elde edilen sonuçlara göre; Türkiye ile Kolombiya ve Türkiye ile Meksika hisse senedi piyasası arasında uzun dönemde anlamlı bir ilişki bulunmuş iken, Türkiye ile diğer gelişmekte olan ülkeler hisse senedi piyasası arasında anlamlı bir ilişki bulunamamıştır.

Yıldız ve Aksoy (2014), Ocak 1990 - Aralık 2011 dönemindeki aylık endeks kapanış değerlerini kullanarak, Morgan Stanley gelişmekte olan ülke piyasa endeksi ile BIST100 endeksi arasındaki eşbütünleşmenin varlığını ve derecesini incelemiştir. Çalışmada, endeksler arasındaki eşbütünleşme Engle- Granger yöntemi ve Hata Düzeltme modeli kullanılarak analiz edilmiştir. Çalışma sonunda, BİST100 ile Morgan Stanley gelişmekte olan ülke piyasa endeksi arasında hem kısa hem de uzun dönemli güçlü bir ilişki tespit edilmiştir.

Akel (2015), "Kırılgan Beşli" olarak adlandırılan ülkelere (Brezilya, Endonezya, Güney Afrika, Hindistan ve Türkiye) ait hisse senedi piyasa endeksleri arasındaki eşbütünleşme ve nedensellik ilişkisini Kasım 2000 - Aralık 2013 döneminde incelemiştir. Bu ilişkileri Johansen 
eşbütünleşme analizi ve Granger nedensellik kullanarak test etmiş ve sonuç olarak, beş ülkenin hisse senedi piyasaları arasında hem kısa hem de uzun dönemli bir eşbütünleşme ve nedensellik ilişkisinin varlığını tespit etmiştir.

Syriopoulos vd. (2015), BRICS ile Amerika arasındaki etkileşimleri ve yayılma etkisini hem finansal piyasalarda hem de ticaret sektöründe araştırmışlardır. Çalışma, küresel finansal krizi de içine alan 3 Ocak 2005 - 31 Aralık 2013 dönemini kapsamaktadır. Analizde, VAR(1)GARCH $(1,1)$ yöntemi kullanılmıştır. Çalışmanın sonucunda, BRICS ve Amerika'nın hem finansal piyasalarında hem de ticaret sektöründe getiri ve oynaklık düzeyinde anlamlı etkileşimlerin varlığı tespit edilmiştir.

Nashier (2015), BRICS finansal piyasaları ile Amerikan ve İngiltere finansal piyasaları arasındaki etkileşimleri, 1 Ocak 2004 - 31 Aralık 2013 döneminde analiz etmiştir. Etkileşimlerin varlığı korelasyon testi ve Johansen eşbütünleşme testi kullanılarak tespit edilmeye çalışılmıştır. Çalışmanın bulgularına göre, kısa dönemde statik, uzun dönemde ise dinamik etkileşimlerin varlığ 1 tespit edilmiştir.

Şimşek (2016), BİST ve BRICS ülkelerinin hisse senedi piyasalarının arasındaki ilişkiyi, 3 Ocak 2008 - 21 Ocak 2015 dönemine ait günlük verileri kullanarak incelemiştir. Analizlerde, doğrusal olmayan koşullu değişen varyans modellerinden $\mathrm{ARCH}$ ve GARCH modelleri kullanılmış ve çalışmanın sonucunda; BIST' in BRICS ülkelerinin gösterge endeksleriyle ilişki içerisinde olduğu ve son dönemde en fazla Hindistan ve Güney Afrika ülkeleriyle ilişkisi bulunduğu sonucuna ulaşmıştır. Ayrıca yine son dönem verilerine göre Türkiye'nin Hindistan hariç diğer borsalardan pozitif olarak ayrıştığı tespit edilmiştir.

Mensi vd. (2016), ABD piyasası ile BRICS hisse piyasaları arasındaki yayılma etkisini incelemişlerdir. Çalışmada, Eylül 1997 ve Ekim 2013 dönemine ait günlük hisse senedi piyasa endeksleri dikkate alınmış ve analiz, küresel kriz öncesi ve sonrası olmak üzere iki döneme ayrılarak gerçekleştirilmiştir. Çalışmada, oynaklık yayılmalarını yakalamak, potansiyel yapısal kırılmaları tespit etmek ve portföy piyasası risklerini değerlendirmek amaçlanmıs ve iki değişkenli DCC-FIAPARCH modeli ve Riske Maruz Değer (VaR) yöntemleri uygulanmıştır. Elde edilen amprik sonuçlar, ABD ile BRICS borsaları arasında önemli dinamik korelasyonların varlığını göstermiştir. Şartlı oynaklıkta ise asimetri ve uzun hafızaya ilişkin güçlü kanitlar sunulmuştur.

Yarovaya vd. (2016) çalışmalarında küresel kriz ve Avrupa bölgesel borç kriz dönemlerini dikkate almışlar ve bu dönemlerde BRICS ve MIST gibi gelişmekte olan piyasalar ile İngiltere piyasaları arasındaki etkileşimleri analiz etmişlerdir. Çalışma, 3 Ekim 2005 - 3 Ekim 2014 dönemini kapsamaktadır. Analizlerde, Asimetrik Genelleştirilmiş Dinamik Koşullu Korelasyon (AG-DCC) yöntemi kullanmışlardır. Elde edilen bulgular, borsalar arasındaki etkileşimin, piyasalarda negatif şok olduğu dönemlerde yani, kriz dönemlerinde daha yüksek bağımlılık gösterdiğini ortaya çıkarmıştır. Ayrıca, Çin borsasının İngiltere yatırımcısı için en cazip seçenek olduğu da çalışmada gösterilmiştir.

Mensi vd. (2017), BRICS ülkeleri ile önde gelen gelişmiş ülke (ABD, Japonya, Fransa, Almanya ve İngiltere) borsaları arasındaki dinamik koşullu ilişkileri çift yönlü DCC-FIAPARCH yöntemi kullanarak araştırmışlardır. Çalışmada, 29 Eylül 1997-14 Ekim 2013 dönemi ele alınmış ve bulgular seçilen borsalar arasında zamana bağlı, anlamlı korelasyonların varlığını göstermiştir. 
Özşahin (2017) çalışmasında BRICS ülkeleri ile Türkiye, hisse senedi piyasaları arasında eşbütünleşme ilişkisinin olup olmadığını 2000-2016 döneminde, aylık MSCI Yükselen Piyasalar Endeks verilerini kullanarak incelemiştir. Carrion-i-Silvestre çoklu yapısal kırılmalı birim kök testi ve Maki çoklu yapısal kırılmalı eşbütünleşme yöntemini uygulayarak yaptığı test sonucunda, Brezilya dışında diğer dört ülkenin menkul kıymetler borsası ile Türkiye borsasının uzun dönemde birlikte hareket ettiği bulgusuna ulaşmıştır.

Vuran ve Türkay (2017) çalışmalarında, BRICS ve MIST ülkeleri hisse senedi piyasaları arasındaki etkileşimi, 2010-2016 döneminde günlük verileri kullanarak incelemişlerdir. EngleGranger, Johansen eşbütünleşme ve Granger nedensellik testlerini kullanmışlardır. EngleGranger eşbütünleşme testine göre BIST100 endeksi ile Brezilya, Rusya, Hindistan, Çin, Güney Afrika, Meksika, Endonezya ulusal borsa endeksleri arasında uzun dönemli bir ilişkinin varlığ 1 tespit edilmiş, ancak BIST100 endeksi ile Güney Kore ulusal borsa endeksi arasında uzun dönemli bir ilişkiye rastlanmamıştır. Johansen eşbütünleşme analizine göre ise incelenen borsa endeksleri arasında çoklu eşbütünleşme olmadığı sonucuna ulaşırken, Granger nedensellik sonucuna göre BIST100 endeksi ile diğer ulusal borsa endeksleri arasında nedensellik olduğu sonucuna ulaşmışlardır.

Kılıç ve Dilber (2017), Türkiye ile BRICS ülkelerinin finansal piyasaları arasındaki ilişkiyi araştırmak için MSCI endekslerini dikkate almışlardır. Çalışmada, 18.02.2013 - 17.02.2017 dönemi günlük verileri kullanılarak kantil regresyon yöntemi uygulanmıştır. Çalışmanın sonucuna göre, BRICS ülkeleri ve Türkiye'nin finansal piyasaları arasında zamana bağlı dinamik ilişkinin varlığı ortaya koyulmuştur.

Polat ve Gemici (2017) çalışmalarında Türk borsası ile BRICS borsaları arasında portföy çeşitlendirmesinin uygun olup olmadığını tespit etmek amacıyla, Türk ve BRICS finansal piyasaları arasında uzun dönem ilişkiyi Haziran 2003 - Haziran 2017 dönemi için test etmişlerdir. ARDL sınır testi yaklaşımını kullanarak yaptıkları analiz sonucunda kısa ve uzun vadede Hint ve Brezilya borsalarının Türk borsası ile arasında ilişki olduğu, kısa vadede ise Rus borsalarının Türk borsasıyla ilişkili olduğu tespit edilmiştir. Bunun yanında Çin ve Güney Afrika borsaları ile Türk borsaları arasında kısa veya uzun vadeli bir ilişki olmadığı sonucuna ulaşmışlardır.

\section{Yöntem}

Çalışmada Jiang ve Zhou (2011) tarafından önerilen MF-X-DMA analizi kullanılmıştır. Bu yöntem fraktal teoriye dayanmaktadır. MF-X-DMA analizi, Podobnik ve Stanley (2008) tarafından önerilen Trendden Arındırılmış Çapraz Korelasyon Analizi (DCCA-Detrended Cross Correlation Analysis) ve Gu ve Zhou (2010) tarafından önerilen Çoklu Fraktal Trendden Arındırılmış Hareketli Ortalama Analizinin (MF-DMA-Multifractal Detrended Moving Average Analysis) birleştirilmesi ile oluşturulmuştur. Bu analiz aşağıda verildiği gibi tanımlanmaktadir.

Gözlem sayıları aynı ve $n=1,2, \ldots$. T olmak üzere, $\left\{x^{1}(n)\right\}$ ve $\left\{x^{2}(n)\right\}$ gibi ortalaması “" olan iki durağan zaman serisi için aşağıda verilen adımlar izlenir.

Adım 1. Serilerin hareketli kümülatif toplamları, (1) kullanılarak hesaplanır: 


$$
\begin{aligned}
& X^{1}(n)=\sum_{i=1}^{n} x^{1}(i), n=1,2, \ldots, T . \\
& X^{2}(n)=\sum_{i=1}^{n} x^{2}(i), n=1,2, \ldots, T .
\end{aligned}
$$

Adım 2. $k$ büyüklüğünde hareketli ortalama fonksiyonu $\tilde{X}^{j}(n)(2)^{\prime}$ de verildiği gibi tanımlanır (Arianos ve Carbone, 2007).

$$
\begin{aligned}
& \tilde{X}^{1}(n)=\frac{1}{k} \sum_{i=-\lfloor k \theta\rfloor}^{\lceil k(1-\theta)\rceil} X^{1}(n-i), \\
& \tilde{X}^{2}(n)=\frac{1}{k} \sum_{i=-\lfloor k \theta\rfloor}^{\lceil k(1-\theta)\rfloor} X^{2}(n-i),
\end{aligned}
$$

burada $\quad k-[(k-1) \theta] \leq n \leq T-[(k-1) \theta]^{\prime}$ dır. $\quad g=k(1-\theta) \in \mathbb{R}$ olmak üzere, $\lceil g\rceil$ fonksiyonu, $g^{\prime}$ den daha büyük ve $g^{\prime}$ den daha küçük olmamak kaydıyla en büyük tamsayı değerini vermektedir. $0 \leq \theta \leq 1$ konum parametresidir. Bu durumda, üç farklı hareketli ortalama yöntemi kullanılabilmektedir. Bu yöntem aşağıda verildiği gibi listelenebilir;

a. $\theta=0$, geriye doğru hareketli ortalama durumudur. Bu durumda, hareketli ortalama hesaplanırken, $k$ gecikme değeri kullanılır (Xu vd., 2005).

b. $\theta=1$ ileriye doğru hareketli ortalama durumudur. Bu durumda, hareketli ortalama hesaplanırken, $k$ gelecek değeri kullanılır (Xu vd., 2005).

c. $\theta=0.5$ merkezi hareketli ortalamayı ifade etmektedir. Bu durumda, hareketli ortalama $\lceil(k-1) / 2\rceil$ gecikme değeri ve $\lfloor(k-1) / 2\rfloor$ gelecek değeri içeren $k$ büyüklüğünde veri noktalarına göre hesaplanır (Xu vd., 2005).

Adım 3. Her bir seri ve ona karşılık gelen hareketli ortalamalar arasındaki farklar çarpılarak, çapraz korelasyonlar (3) kullanılarak elde edilir.

$$
C C(i)=\left[X^{1}(n)-\tilde{X}^{1}(n)\right]\left[X^{2}(n)-\tilde{X}^{2}(n)\right],
$$

burada, $i=1,2, \ldots, T-k+1$ ve $n=i+k-\lceil(k-1) \theta\rceil-1$.

Adım 4. Çapraz korelasyonlar, $C C(i), k$ eşit uzunlukta birbiri ile örtüşmeyen, $T_{k}=$ tamsayı $\left(\frac{T-k+1}{k}\right)$ parçaya bölünür. Genellikle, $T-k+1$, parça uzunluğu $k$ 'nin bir katı değildir. Bu nedenle, Cao vd. (2014) $C C(i)^{\prime}$ yi, $i=1,2, \ldots, k \times T_{k}$ ve $i=2, \ldots, k \times T_{k}+1$ için ayrı ayrı hesaplamayı önermişlerdir. Bu şekilde, $2 T_{k}$ parça elde edilmiştir.

Adım 5. Her bir parça, $v=1,2, \ldots, 2 T_{k}$, için çapraz korelasyon fonksiyonu (4) kullanılarak hesaplanir.

$$
F(k, v)=\frac{1}{k} \sum_{i=l_{v}+1}^{l_{v}+k} C C(i),
$$

burada $l_{v}=(v-1) k$.

Adım 6. q. sıradaki çapraz korelasyon dalgalanma (fluctuation) fonksiyonu tüm parçaların ortalaması alınarak (5) ve (6)' da verildiği gibi hesaplanır. $\forall q \neq 0$. 


$$
F_{x y}(q, k)=\left\{\frac{1}{2 T_{k}} \sum_{v=1}^{2 T_{k}}|F(k, v)|^{q / 2}\right\}^{1 / q},
$$

ve $q=0$ için

$$
F_{x y}(0, k)=\exp \left\{\frac{1}{4 T_{k}} \sum_{v=1}^{2 T_{k}} \ln |F(k, v)|\right\} .
$$

Adım 7. $\mathrm{F}_{\mathrm{xy}}(q, k)$ kuvvet-kuralı gösteriyor ise, iki seri uzun dönem çapraz korelasyona sahiptir. Diğer bir deyişle; iki serinin arasında uzun dönem ilişki olması durumunda,

$$
F_{x y}(q, k) \sim k^{H_{x y}(q)}
$$

olarak ifade edilebilmektedir. Burada, $H_{x y}(q)$ Çapraz Korelasyon Ölçekleme Kuvveti'ni göstermektedir ve iki farkl1 yöntem kullanılarak tahmin edilebilmektedir.

I.YÖNTEM: (7)'nin logaritması alınır ve elde edilen (8), doğrusal denklemi regresyon yöntemi ile tahmin edilir (Cao vd., 2014).

$$
\ln \left(F_{x y}(q, k)\right)=H_{x y}(q) \ln k+\ln c,
$$

burada, c, sabit katsayıyı göstermektedir.

II.YÖNTEM: Bu yöntem, grafiksel yöntemdir (Mun, 2012; Pal, Rao ve Manimaran, 2014; Mandelbrot, 1977; Mandelbrot, 1972). Bu yöntemde, $H_{x y}(q)$, değerleri $\ln \left(F_{x y}(q, k)\right)$ 'nin, lnk'ya göre değişim grafiğinin eğiminden elde edilir.

Adım 8. $H_{x y}(q)^{\prime}$ nın farklı $q$ değerleri için grafiği çizilir ve grafikten, güç-kuralı çapraz korelasyonların varlığı gösterilir. Burada, üç durum söz konusu olabilmektedir.

a. $H_{x y}(q)<0.5$, ise uzun dönem çapraz korelasyon kalıcı değildir.

b. $H_{x y}(q)>0.5$, ise uzun dönem çapraz korelasyon kalıcıdır.

c. $\mathrm{H}_{\mathrm{xy}}(\mathrm{q})=0.5$, ise çapraz korelasyon yoktur.

Ayrıca, çapraz korelasyonun multifraktal doğası, ölçeklendirme kuvveti, $\mathrm{H}_{\mathrm{xy}}(\mathrm{q})$ 'nun $q$ ' ya göre değişiminden gözlemlenebilir. $\mathrm{H}_{\mathrm{xy}}(\mathrm{q})$, q'ya bağlıysa, o zaman çapraz korelasyonlar multifraktal bir yapıya sahiptir. Aksi hâlde, çapraz korelasyonlar monofraktaldır.

\section{Veri ve Analiz}

Bu bölümde öncelikle kullanılacak veri ve verinin temel özellikleri tanıtılmıştır. Daha sonra analiz sonuç ve bulguları sunulmuştur.

\section{Veri}

Çalışmada, BRICS ülkeleri ve Türkiye'ye ait MSCI ETF endeksleri kullanılmıştır. Veriler, Yahoo! Finance $^{1}$ veri tabanından elde edilmiştir. Endeksler arasında, Hindistan'a ait MSCI ETF endeksi en son oluşturulan endekstir ve 2 Şubat 2012 tarihinde ilk işlem gerçekleşmiştir. Bu nedenle, çalışma, 3 Şubat 2012-1 Haziran 2018 dönemini kapsamaktadır. Örneklem toplam 1591 günlük kapanış fiyat verisi içermektedir. Çalışmanın analizleri, $R$ programı kullanılarak gerçekleştirilmiştir. 
MSCI Türkiye ETF Endeksi Fiyat Serisi

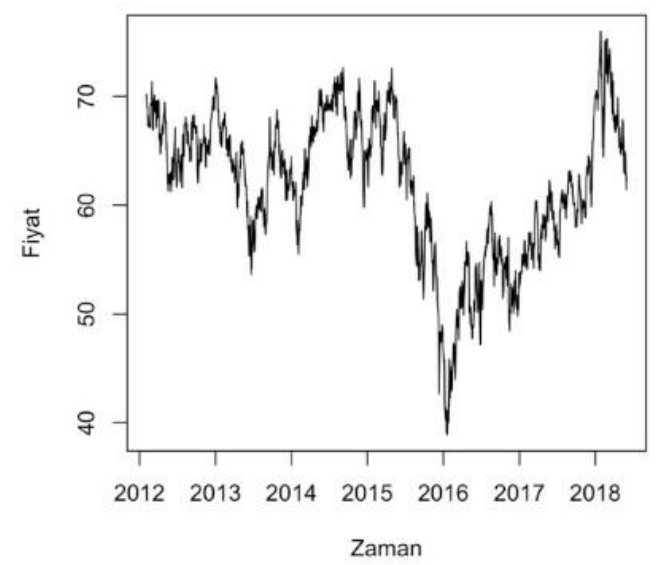

MSCI Rusya ETF Endeksi Fiyat Serisi

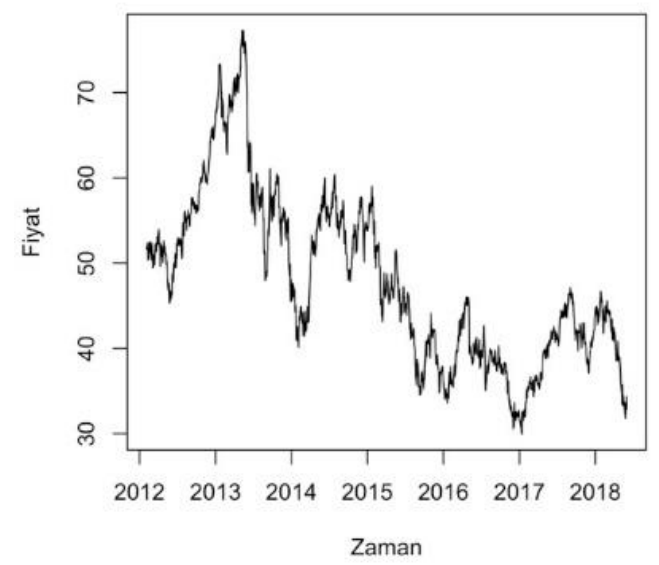

MSCI Çin ETF Endeksi Fiyat Serisi

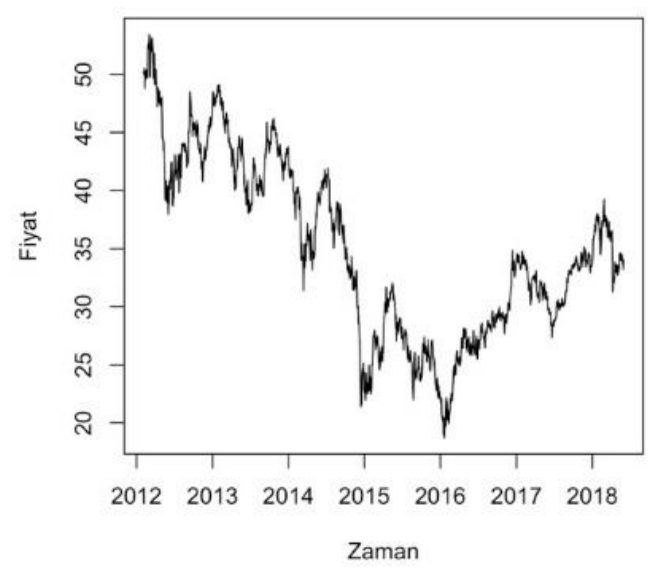

MSCI Brezilya ETF Endeksi Fiyat Serisi

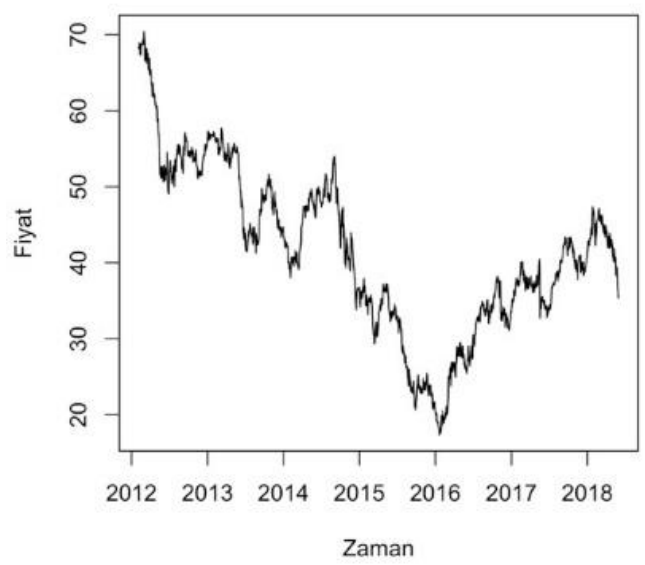

MSCI Hindistan ETF Endeksi Fiyat Serisi

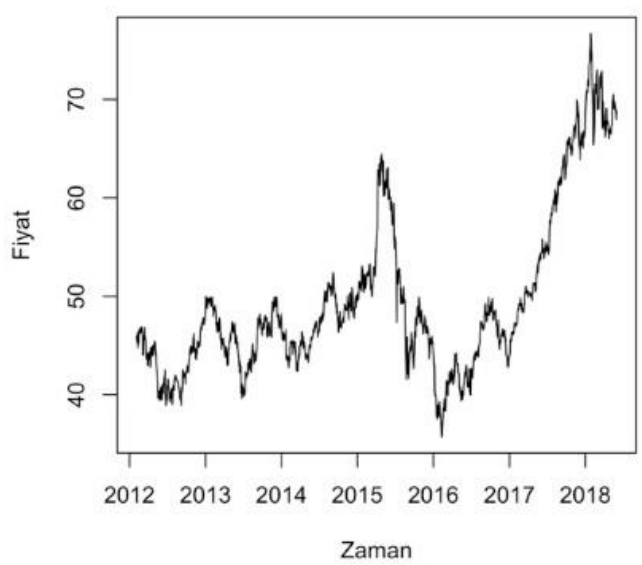

MSCI Güney Afrika ETF Endeksi Fiyat Serisi

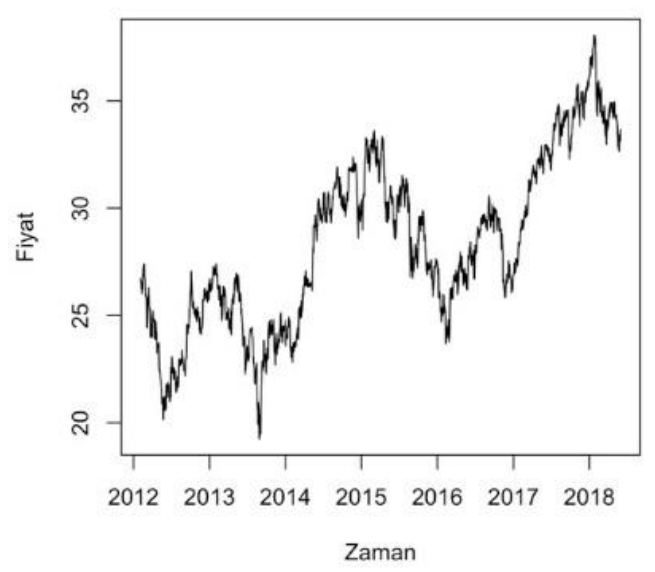

Şekil 1: MSCI ETF Endeksleri Fiyat Seri Grafikleri

Şekil 1'de MSCI Türkiye ETF endeksi ve BRICS ülkelerine ait ETF endekslerinin kapanış fiyatlarına ait zamana bağlı değişim grafikleri sunulmuştur. Şekle göre, incelenen ETF 
endekslerinin hepsinin 2015 başlarından 2016 yılına kadar keskin bir düşüş yaşadığ1 gözlemlenmektedir. Ayrıca, MSCI Türkiye ETF, MSCI Brezilya ETF, MSCI Hindistan ETF ve MSCI Çin ETF endekslerinin, en düşük değerlerini 2016 yılı başlarında aldığı tespit edilmiştir.

Analizlere, getiri serileri kullanılarak devam edilmiştir. Bu nedenle, ilk olarak günlük fiyat serilerinin birincil logaritmik farkı 100 ile çarpılarak yüzde getiri serileri;

$$
\left(r_{t}=100 \times\left(\log \left(p_{t}\right)-\log \left(p_{t-1}\right)\right)\right)
$$

formülü kullanılarak elde edilmiştir. Burada, $p_{t}, t$ anında gözlemlenen hisse fiyatını göstermektedir.

Şekil 2'de MSCI Türkiye ETF endeksi ve BRICS ülkelerine ait ETF endekslerinin getirilerine ait zamana bağlı değişim grafikleri sunulmuştur. Şekle göre tüm endekslere ait getiri serilerinde oynaklık kümelenmesi tespit edilmiştir. Aynı zamanda, Çin ve Hindistan'a ait MSCI ETF endeks getirilerinin oynaklıkları diğer endekslere oranla oldukça az olduğu gözlemlenmiştir.
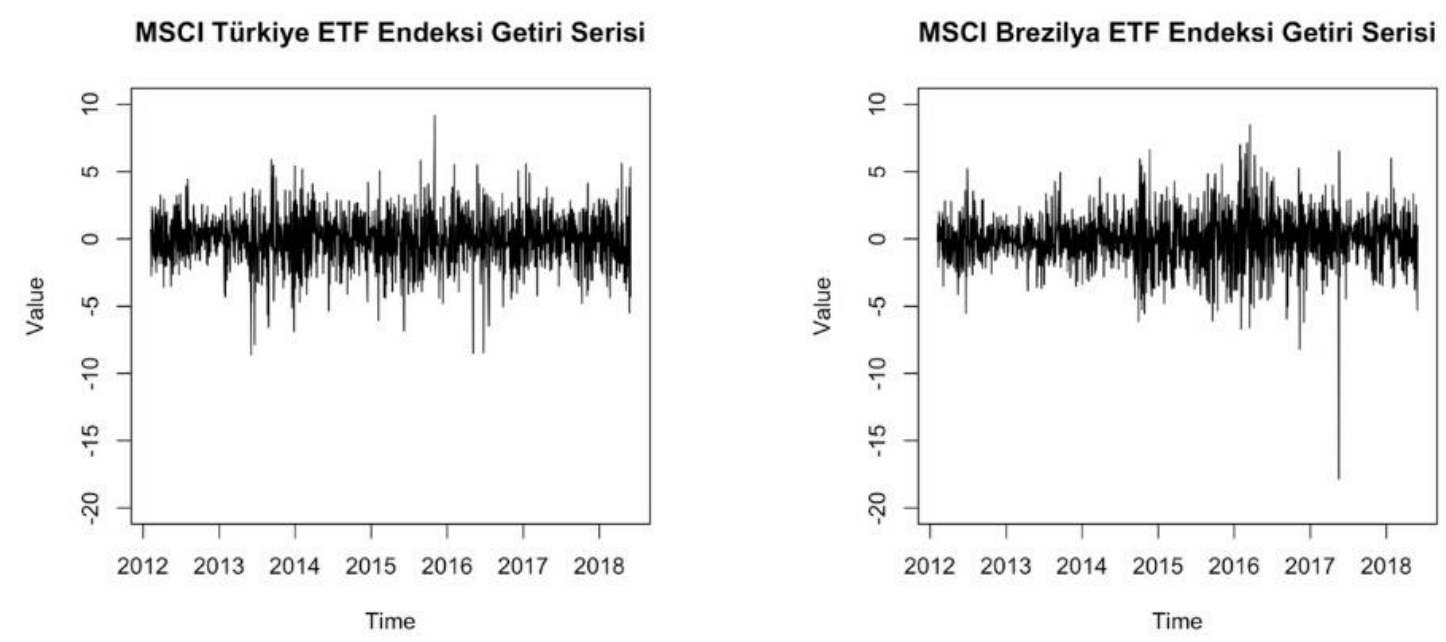

MSCI Rusya ETF Endeksi Getiri Serisi

MSCI Hindistan ETF Endeksi Getiri Serisi
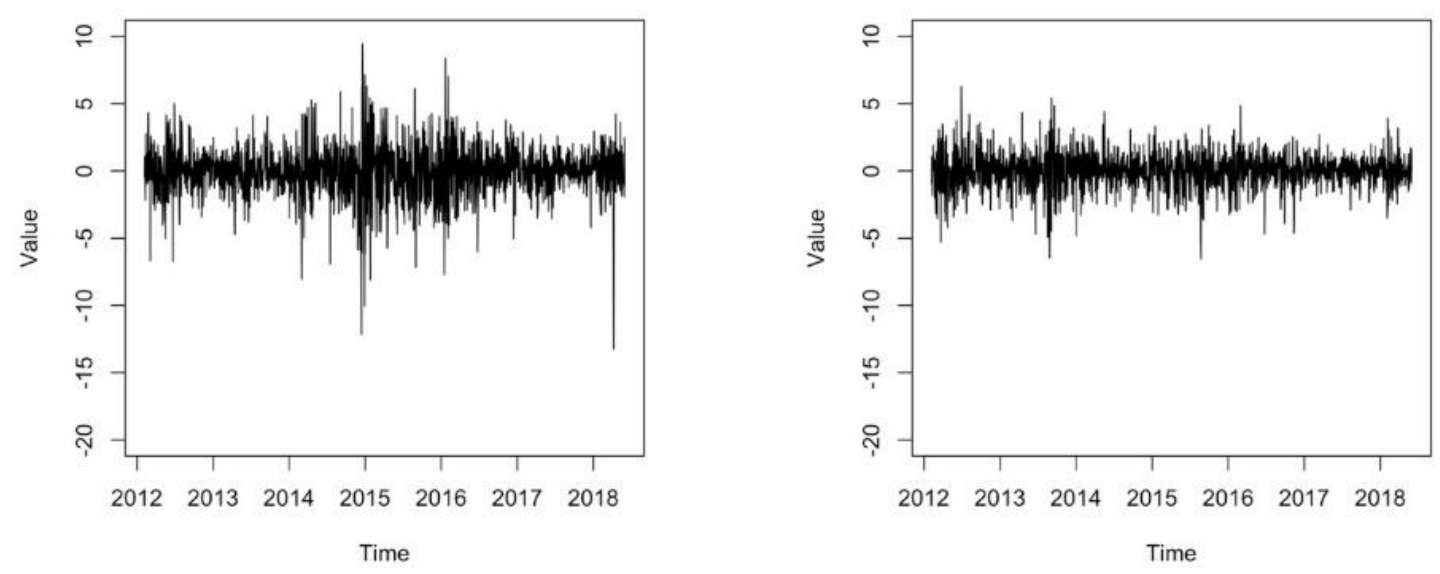

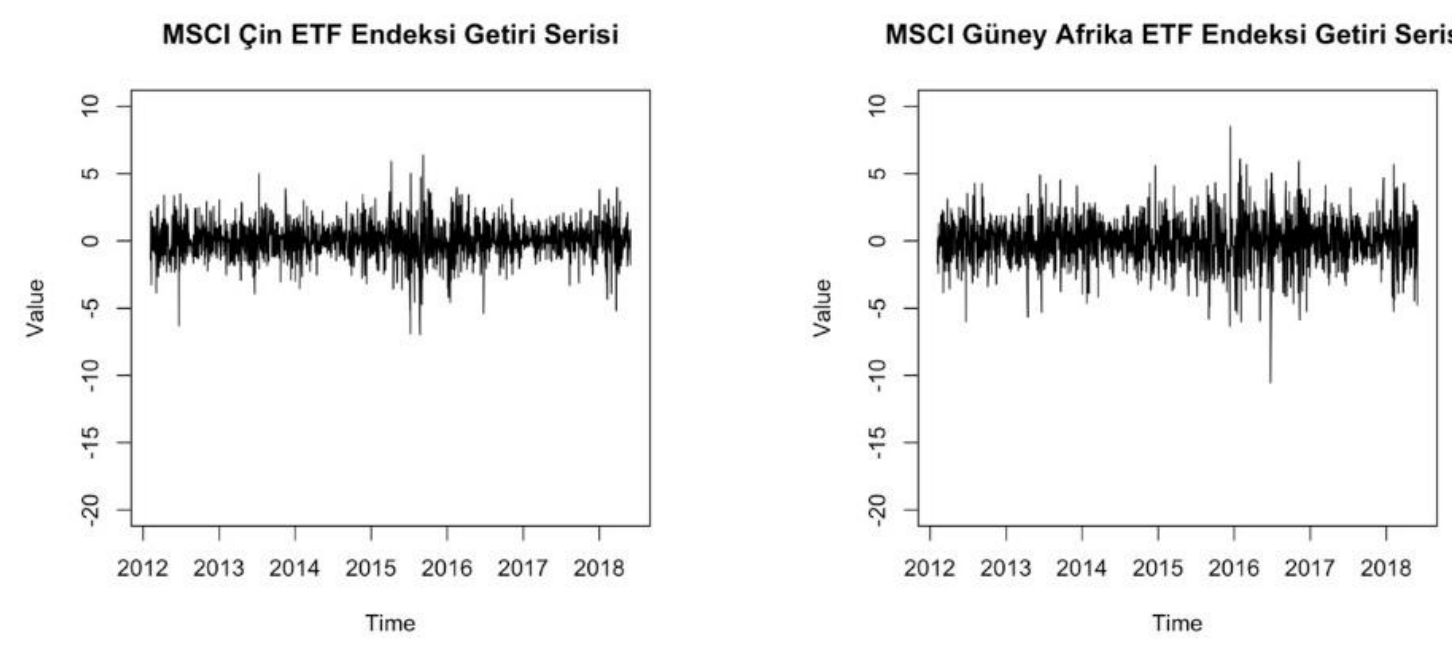

Şekil 2: MSCI ETF Endeksleri Getiri Seri Grafikleri

Tablo 1.'de MSCI ETF endeks getirilerine ait temel tanımlayıcı istatistikler sunulmuştur. Tabloya göre verilen dönem içinde ortalamada en çok kazandıran MSCI Çin ETF endeksi iken ortalamada en az kazandıran (ya da ortalamada en fazla kaybettiren) MSCI Brezilya ETF endeksi olarak tespit edilmiştir. Verilen dönem içinde standart sapmalara göre riski en fazla MSCI Rusya ETF endeksi ve riski en az ise MSCI Hindistan ETF endeksi olarak gözlemlenmiştir. Bununla birlikte, 1 günde en fazla kazandıran endeks MSCI Rusya ETF endeksidir. MSCI Rusya endeksi 1 günde en çok \% 9,4552 kazandırmıştır. Aynı dönemde, 1 günde en fazla kayıp yaşatan MSCI Brezilya ETF endeksidir ve 1 günde \% 17,8242 kayıp yaşatmıştır.

Tablo 1: MSCI ETF Endeks Getirilerine Ait Tanımlayıcı İstatistikler

\begin{tabular}{cccccccc}
\hline & Ortalama & Medyan & Min. & Maks. & $\begin{array}{c}\text { St. } \\
\text { Sapma }\end{array}$ & Çarpıklık & Basıklık \\
\hline Türkiye & $-0,0284$ & 0,0241 & $-8,6146$ & 9,1781 & 1,8787 & $-0,2637$ & 1,5389 \\
Brezilya & $-0,0409$ & $-0,0243$ & $-17,8242$ & 8,4780 & 1,9514 & $-0,4289$ & 5,1582 \\
Rusya & $-0,0251$ & 0 & $-13,2373$ & 9,4552 & 1,9608 & $-0,4460$ & 3,8436 \\
Hindistan & 0,0145 & 0 & $-6,5354$ & 6,2649 & 1,3615 & $-0,2196$ & 1,7313 \\
Çin & 0,0254 & 0,0265 & $-6,9682$ & 6,3683 & 1,3712 & $-0,1846$ & 2,2249 \\
G. Afrika & $-0,0076$ & 0,0304 & $-10,5320$ & 8,5134 & 1,7666 & $-0,1920$ & 1,6708 \\
\hline
\end{tabular}

Tablo 1'de sunulan çarpıklık katsayı değerlerine göre tüm endekslere ait getiri dağılımlarının sola kuyruklu olduğu söylenebilir. Çarpıklık katsayılarını basıklık katsayıları ile birlikte değerlendirdiğimizde ise getiri dağılımlarının normallikten saptığı söylenebilmektedir. Getiri serilerinin normal dağılım izlediği $H_{0}$ hipotezini test etmek için Jarque Bera Normallik testi (Jarque ve Bera, 1980) ve getiri serilerinin durağanlık varsayımını test etmek için ise Augmented Dickey Fuller (ADF) durağanlık testi kullanılmıştır (Dickey ve Fuller, 1979, 1981). Tablo 2' de bu test sonuçları yer almaktadır. 
Tablo 2: Jarque-Bera ve ADF Test Sonuçları

\begin{tabular}{lcccc}
\hline & $\begin{array}{c}\text { Jarque-Bera } \\
\text { Test İstatistiği }\end{array}$ & Olasılık & $\begin{array}{c}\text { ADF } \\
\text { Test İstatistiği }\end{array}$ & Olasılık \\
\hline Türkiye & 176,5271 & 0,0000 & $-11,5332$ & 0,0000 \\
Brezilya & 1818,5951 & 0,0000 & $-10,9928$ & 0,0000 \\
Rusya & 1035,9481 & 0,0000 & $-11,3476$ & 0,0000 \\
Hindistan & 212,7567 & 0,0000 & $-11,8428$ & 0,0000 \\
Çin & 338,9364 & 0,0000 & $-11,8177$ & 0,0000 \\
G. Afrika & 196,0295 & 0,0000 & $-12,7249$ & 0,0000 \\
\hline
\end{tabular}

Sonuçlara göre $\alpha=0,05$ anlamlılık düzeyinde getiri serilerinin, normal dağılım izlemediği ve tüm getiri serilerinin durağan olduğu tespit edilmiştir.

\section{Analiz}

Çalışmanın bu bölümünde Türkiye ile BRICS ülkeleri arasındaki uzun dönem kuvvet kuralı çapraz korelasyonların tespiti amaçlı MF-X-DMA analizi getirilerin oynaklık serilerine uygulanmıştır. Analizde oynaklık serisi olarak mutlak getiri serisi kullanılmıştır.

Çapraz Korelasyon Testi

Çapraz korelasyonların tespiti amaçlı Podobnik vd. (2009) tarafından önerilen test kullanılmıştır. Test istatistiği ve yöntemine ait bilgiler aşağıda sunulmuştur.

$\left\{x^{1}(n)\right\}$ ve $\left\{x^{2}(n)\right\}$, aynı sayıda gözlem, $T$ içeren iki seri olsun. Test istatistiği,

$$
Q_{c c}(l)=T^{2} \sum_{i=1}^{l} \frac{X^{2}(i)}{T-i},
$$

olarak tanımlanır. Burada, $l$, kullanılan gecikme sayısı ve $X(i)$ ise çapraz korelasyon fonksiyonudur.

$$
X(i)=\frac{\sum_{n=i+1}^{T} x^{1}(n) x^{2}(n-i)}{\sqrt{\sum_{k=1}^{T}\left(x_{k}^{1}\right)^{2}} \sqrt{\sum_{k=1}^{T}\left(x_{k}^{2}\right)^{2}}} .
$$

$Q_{c c}(l)$ test istatistiği, $\chi^{2}(l)(l$ : serbestlik derecesi) dağllımına sahiptir. Testin hipotezleri aşağıda verildiği gibi tanımlanır.

$H_{0}$ : Seriler arasında çapraz korelasyonlar yoktur.

$H_{1}$ : Seriler arasında çapraz korelasyonlar vardır.

Çalışmada, bahsi geçen test BRICS ülkelerinin finansal piyasa oynaklıklarının, Türkiye'nin finansal piyasa oynaklığına ait etkisinin varlığını tespit amaçlı uygulanmıştır.

Şekil 3'te, $l: 1,2,3, \ldots, 1000$ değerleri alınarak, $Q_{c c}(l)$ test istatistikleri ve $\alpha=0.05$ anlamlılık düzeyinde, $\chi^{2}(l)$ tablo değerleri sunulmuştur. Şekile göre, Türkiye ile tüm BRICS ülkelerinin oynaklıklarına ait çapraz korelasyon istatistikleri, her gecikme değeri, $l$ için $\chi^{2}(l)$ tablo değerlerinden oldukça büyüktür. Bu nedenle, $\alpha=0.05$ anlamlılık düzeyinde Türkiye ile BRICS ülkeleri arasında çapraz korelasyonların varlığı söylenebilir. 


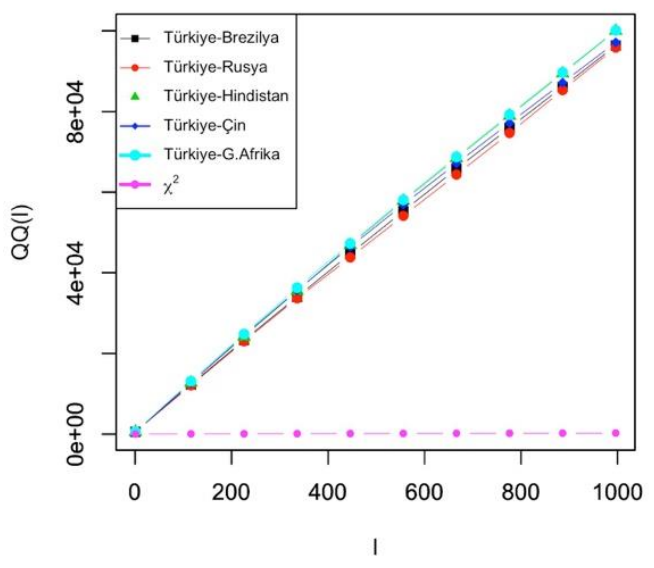

Şekil 3: Çapraz Korelasyon İstatistikleri $\mathrm{Q}_{\mathrm{cc}}(\mathrm{l})$ ve $\chi^{2}(l)$ Tablo Değerleri $(\alpha=0.05)$

\section{MF-X-DMA Analiz Sonuçları}

Jiang ve Zhou (2011) çalışmalarında, MF-X-DMA analizi için hareketli ortalama yönteminin önemini vurgulamış ve oynaklık serileri için kullanıldığında ileriye doğru ve geriye doğru hareketli ortalama kullanılmasını önermişlerdir. Bu nedenle bu çalışmada, geriye doğru hareketli ortalama, $\theta=0$ uygulanarak, MF-X-DMA analizi gerçekleştirilmiştir.

MF-X-DMA'ya bağlı uzun dönem kuvvet-kuralı çapraz korelasyon analizi sayısal olarak çapraz korelasyonun varlığını araştırmaktadır. Bu amaçla, q değerleri için $[-8,+8]$ aralığında 81 farklı değer ve pencere uzunluğu $\mathrm{k}$ için ise $\mathrm{k}=[20,25,32,40,50,63,79,100,126$, 158, 200, 251,316] değerleri alınmıştır.

Şekil 4'te, Türkiye ve BRICS ülkelerinin oynaklıklarına ait çapraz korelasyon dalgalanma fonksiyonu, Fxy (q , k)'nın, parça uzunluğu, k’ya göre değişim grafiği verilmiştir. Şekil 4'e göre tüm çapraz korelasyon dalgalanma fonksiyonları, Fxy $(\mathrm{q}, \mathrm{k})^{\prime}$ lerin her q değeri için k'nın doğrusal birer fonksiyonu olduğu gözlemlenmektedir. $\mathrm{Bu}$ sonuç, Türkiye-Brezilya oynaklıkları, Türkiye-Rusya oynaklıkları, Türkiye-Hindistan oynaklıkları, Türkiye-Çin oynaklıkları ve Türkiye-Güney Afrika oynaklıkları arasında güç-kuralı çapraz korelasyonların yani uzun dönem çapraz korelasyonların varlı̆̆ını göstermektedir.
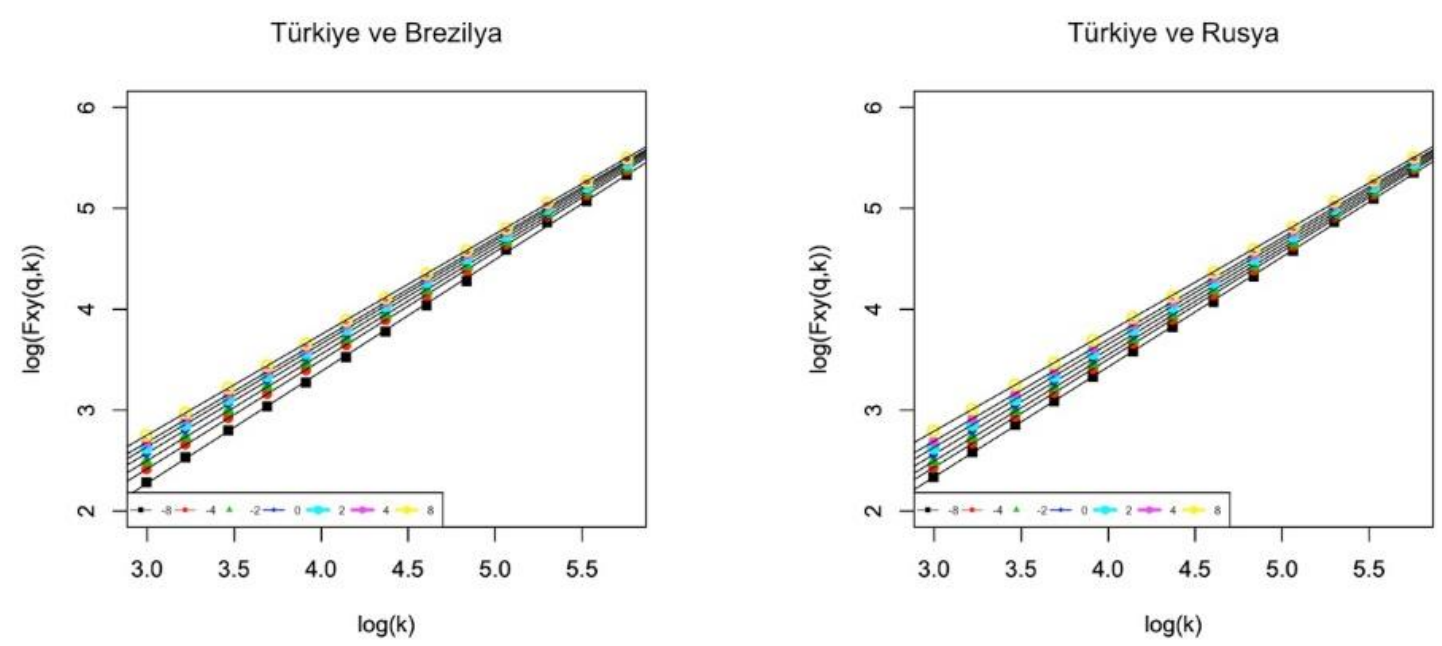
Türkiye ve Hindistan

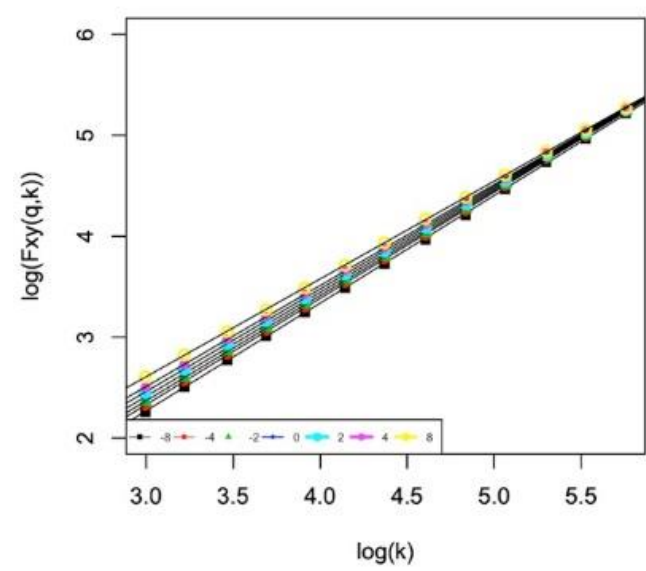

Türkiye ve Güney Afrika

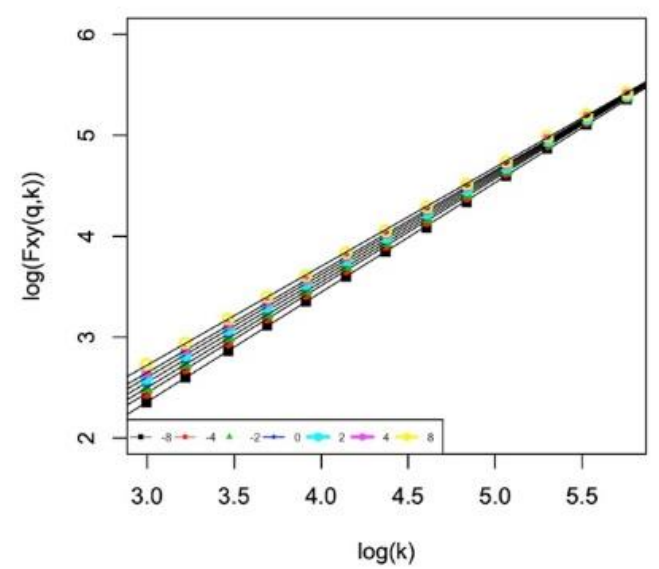

Türkiye ve Çin

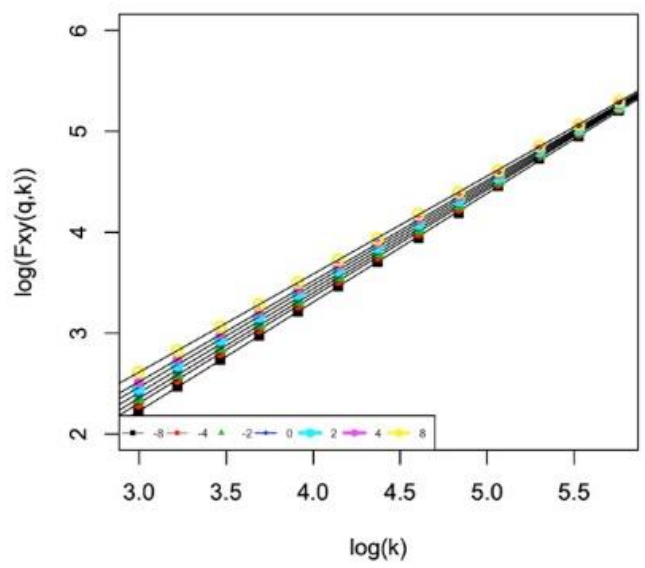

Şekil 4. Çapraz Korelasyon Dalgalanma Fonksiyonu, Fxy $(q, k)^{\prime}$ Nın Parça Uzunluğu, $k^{\prime} a$ Göre Değişimine Ait Log-Log Grafiği

Zamana bağlı çapraz korelasyonların uzun dönem davranışlarının tespit edilebilmesi için ölçekleme kuvveti $H_{x y}(q)$ 'nin $q^{\prime}$ ya göre değişim grafikleri Şekil $5^{\prime}$ te sunulmuştur. $H_{x y}(q)$ değerleri (8)'de verilen regresyon denkleminin eğim katsayısıdır ve en küçük kareler yöntemi ile tahmin edilmiştir. Ayrıca, çapraz korelasyonların uzun dönem kalıcı olup olmadığının tespiti için ölçekleme kuvveti $H_{x y}(q)^{\prime}$ nin $q=\{-8,-4,-2,0,2,4,8\}$ değerlerine göre değişimleri de Tablo 3'de sunulmuştur. Şekil 5'e göre $H_{x y}(q)$ değerleri $q$ 'nun doğrusal olmayan bir fonksiyonudur. Bu nedenle, Türkiye-Brezilya oynaklıkları, Türkiye-Rusya oynaklıkları, Türkiye-Hindistan oynaklıkları, Türkiye-Çin oynaklıkları ve Türkiye-Güney Afrika oynaklıkları arasındaki çapraz korelasyonların multifraktal yapıda olduğu söylenebilir. 

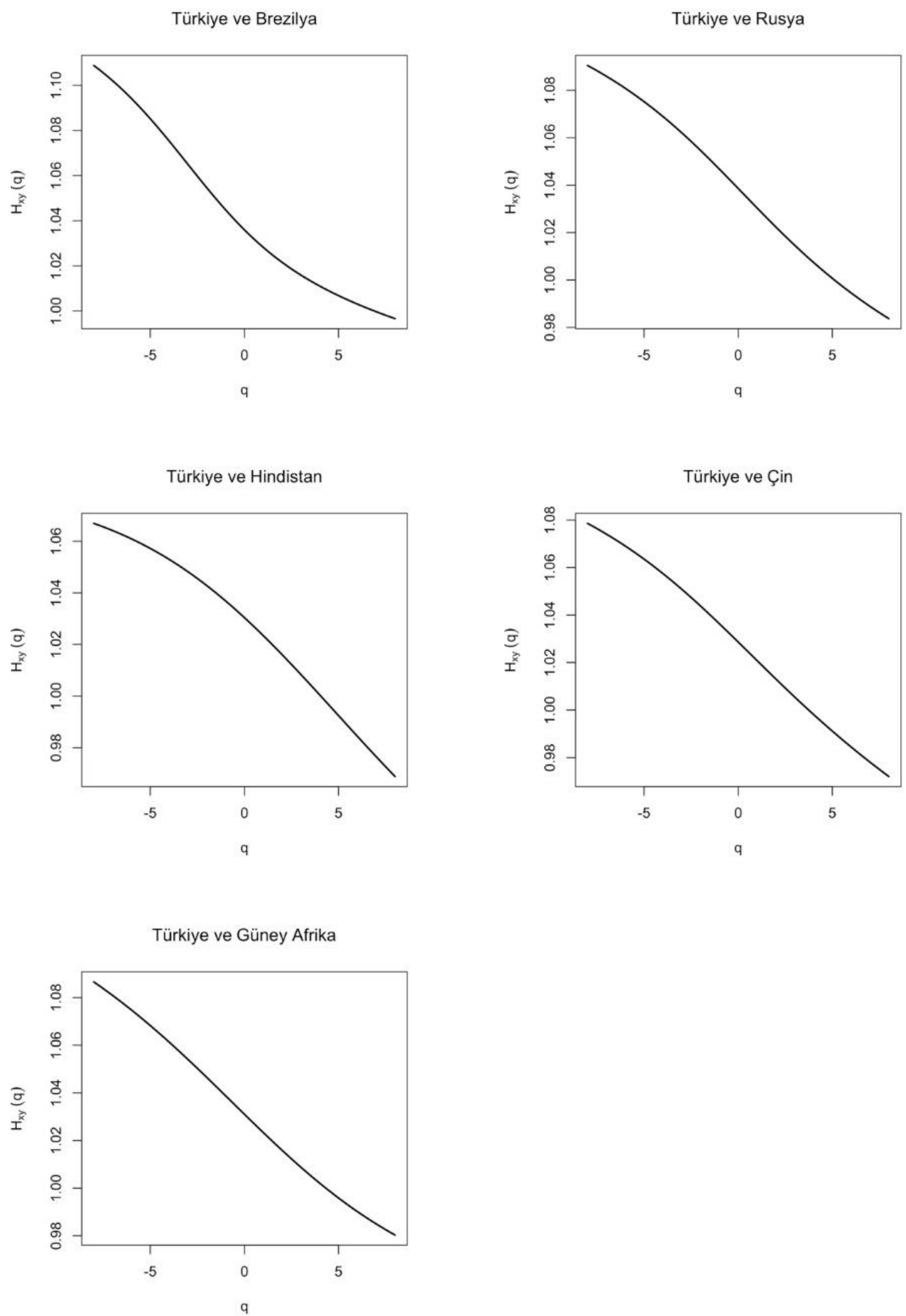

Şekil 5: Çapraz Korelasyon Ölçekleme Kuvveti, $\boldsymbol{H} \boldsymbol{x} \boldsymbol{y}(\boldsymbol{q})$ 'nun $\boldsymbol{q}^{\prime}$ ya Göre Değişimine Ait Grafik 
Tablo 3 ve Şekil 5'i birlikte değerlendirdiğimizde tüm seriler ve tüm $q$ değerleri için $H_{x y}(q)>$ 0.95 olduğu gözlemlenmektedir. Bu sonuç, Türkiye ile BRICS ülkelerinin oynaklıkları arasında güçlü uzun dönem çapraz korelasyonlar olduğunu belirtir. Ayrıca, $q$ değerleri için $H_{x y}(q)>0.95$ olması, hem küçük şokların $(q<0)$ hem de büyük şokların $(q>0)$ etkisinin çapraz korelasyonlarda uzun dönem kalıcı olduğunun göstergesidir.

Tablo 3: Çapraz Korelasyon Ölçekleme Kuvveti, $\boldsymbol{H}_{\boldsymbol{x}}$ 'nin Farklı $\boldsymbol{q}$ Değerlerine Göre Değeri

\begin{tabular}{cccccc}
\hline & $\begin{array}{c}\text { Türkiye } \\
\text { ve } \\
\text { Brezilya }\end{array}$ & $\begin{array}{c}\text { Türkiye } \\
\text { ve } \\
\text { Rusya }\end{array}$ & $\begin{array}{c}\text { Türkiye } \\
\text { ve } \\
\text { Hindistan }\end{array}$ & $\begin{array}{c}\text { Türkiye } \\
\text { ve } \\
\text { Çin }\end{array}$ & $\begin{array}{c}\text { Türkiye } \\
\text { ve } \\
\text { G. Afrika }\end{array}$ \\
\hline-8 & 1,1087 & 1,0904 & 1,0669 & 1,0786 & 1,0866 \\
-4 & 1,0753 & 1,0689 & 1,0530 & 1,0575 & 1,0614 \\
-2 & 1,0546 & 1,0546 & 1,0428 & 1,0438 & 1,0465 \\
0 & 1,0360 & 1,0386 & 1,0304 & 1,0286 & 1,0310 \\
2 & 1,0216 & 1,0223 & 1,0160 & 1,0131 & 1,0159 \\
4 & 1,0111 & 1,0074 & 1,0004 & 0,9981 & 1,0021 \\
8 & 0,9966 & 0,9837 & 0,9688 & 0,9720 & 0,9803 \\
\hline
\end{tabular}

\section{Sonuç}

Çalışmada, Türkiye ile BRICS ülkelerinin oynaklıkları (volatiliteleri) arasında çapraz korelasyonların varlığ 1 MSCI ETF endekslerine ait getirilerin, volatilite serileri kullanılarak araştırılmıştır. 3 Şubat 2012-1 Haziran 2018 dönemi dikkate alınarak öncelikle TürkiyeBrezilya oynaklıkları, Türkiye-Rusya oynaklıkları, Türkiye-Hindistan oynaklıkları, TürkiyeÇin oynaklıkları ve Türkiye-Güney Afrika oynaklıkları arasındaki çapraz korelasyonların varlığı Çapraz Korelasyon testi ile ortaya konulmuştur. MF-X-DMA analizi sonucunda ise Türkiye ile BRICS ülkelerinin volatiliteleri arasında güç-kuralı çapraz korelasyonların yani uzun dönem çapraz korelasyonların var olduğu sonucuna ulaşılmıştır. Bu nedenle, BRICS ülkelerinden birinde yaşanan bir şokun etkisinin Türkiye üzerinde uzun dönemde de etkisinin görüleceği sonucuna varılabilir.

$\mathrm{Bu}$ bilimsel çalışmada kullanılan, MSCI endekslerin uluslararası yatırımcılar için birer gösterge niteliği taşıdığı dikkate alındığında, yapılan analizler sonucunda elde edilen bulgulara göre, uluslararası yatırımlarda, yatırımcıların uzun dönemli bu ilişkilerin varlığını dikkate almaları ve yatırım alternatifleri arasından seçimlerini bu doğrultuda gerçekleştirmeleri, yatırımlarının korunması açısından faydalı olacağı söylenebilir.

\section{Kaynakça}

Ağır, H. ve Yıldırım, S. (2015). Türkiye ile BRICS Ekonomilerinin Makroekonomik Performans Karşılaştırması: Betimsel Bir Analiz. KSÜ Sosyal Bilimler Dergisi /KSU Journal of Social Sciences, 12(2), 39-66.

Akal, M. (2013). BIST-100 Endeksi ile GSPTSE ve Yükselen Borsalar Arası Etkileşim. Akademik Bakış Dergisi, 38, 1-18.

Akel, V. (2015). Kırılgan Beşli Ülkelerinin Hisse Senedi Piyasaları Arasındaki Eşbütünleşme Analizi, Uluslararası Yönetim İktisat ve İşletme Dergisi, 11(24), 75-96. 
Arianos, S. ve Carbone, A. (2007). Detrending Moving Average Algorithm: A Closed-Form Approximation of The Scaling Law. Physica A: Statistical Mechanics and its Applications, 382(1), 9-15.

Benli, Y K. (2014). Türkiye Borsasının Gelişmekte Olan Ülkeler Borsaları ile Eşbütünleşme Analizi. Yönetim ve Ekonomi Araştırmaları Dergisi, 23, 18-32.

Boubaker, H. ve Raza, S. A. (2017). A Wavelet Analysis of Mean and Volatility Spillovers Between Oil and BRICS Stock Markets. Energy Economics, 64, 105-11.

Bozoklu, Ş. ve Saydam, İ.M. (2010). BRIC Ülkeleri ve Türkiye Arasındaki Sermaye Piyasaları Entegrasyonunun Parametrik ve Parametrik Olmayan Eşbütünleşme Testleri ile Analizi. Maliye Dergisi, 159, 416-431.

Cao, G., Han, Y., Chen, Y. ve Yang, C. (2014). Multifractal Detrended Cross-Correlation Between The Chinese Domestic and International Gold Markets Based on DCCA and DMCA Methods. Modern Physics Letters, 28-11, 1450090.

Chkili, W. ve Nguyen, D.K. (2014). Exchange Rate Movements and Stock Market Returns in A Regime-Switching Environment: Evidence for BRICS Countries. Res. Int. Bus. Financ. 31, 4656

Dickey, D. A. ve Fuller, W. A. (1979). Distribution of The Estimators for Autoregressive Time Series with Unit Root. Journal of the American Statistical Association, 74, 427-431.

Dickey, D. A. ve Fuller, W. A. (1981). Likelihood Ratio Statistics for Autoregressive Time Series with a Unit Root. Econometrica, 49(4), 1057-1072.

Evlimoğlu, U. ve Çondur, F. (2012). İMKB ile Bazı Gelişmiş ve Gelişmekte Olan Ülke Borsaları Arasındaki Karşılıklı Bağlantıların Küresel Kriz Öncesi ve Sonrası Dönem İçin İncelenmesi. Uludağ Üniversitesi İktisadi ve İdari Bilimler Fakültesi Dergisi, 31(1), 31- 58.

Gilmore, C. G. ve McManus, G. M. (2002). International Portfolio Diversification: US and Central European Equity Markets. Emerging Markets Review, 3(1), 69-83.

Goldman Sachs. (2001). Building Better Global Economic BRICs, written by Jim O'Neill. Global Economics Paper No: 66, http://www.goldmansachs.com/our-thinking/archive/archivepdfs/build-better-brics.pdf.

Gu, G.-F. ve Zhou, W.-X.(2010). Detrending Moving Average Algorithm for Multifractals. Phys. Rev., 82(1), 011136.

Jarque, C. ve Bera, A. (1980). Efficient Tests for Normality Homoscedasticity and Serial Independence of Regression Residuals. Econometric Letters, 6, 255-259.

Jiang, Z.Q. ve Zhou, W.X. (2011). Multifractal Detrending Moving Average Cross-Correlation Analysis. Phys. Rev., 84, 016106.

Kang, S.H. ve McIver, R. ve Yoon, S.M. (2016). Modeling Time-Varying Correlations in Volatility Between BRICS and Commodity Markets. Emerging Markets Finance and Trade, 52:7, 1698-1723.

Kılıç, R. ve Dilber C. (2017). Türkiye ve BRİCS Ülkelerinin Finansal Piyasaları Arasındaki İlişkinin Kantil Regresyon Yöntemi ile İncelenmesi. Akademik Sosyal Araştırmalar Dergisi, 5(48), 331-342. 
Ma, F., Wei, Y., Huang D. ve Zhao L. (2013). Cross-Correlations Between West Texas Intermediate Crude Oil and the Stock Markets of the BRIC. Physica A: Statistical Mechanics and its Applications. 392(21), 5356-5368.

Mandelbrot, B. B. (1972). Possible Refinements of the Lognormal Hypothesis Concerning the Distribution of Energy Dissipation in Intermitent Turbulence. Statistical Models and Turbulence, New York: Springer Verlag. 333-351.

Mandelbrot, B. B. (1974). Intermittent Turbulence in Self Similar Cascades; Divergence of High Moments and Dimension of the Carrier. Journal of Fluid Mechanics, 62, 331-358.

Mandelbrot, B. B. (1977). Fractals: Form, Chance and Dimension, San Francisco: Freeman.

Mensi, W., Hammoudeh, S., Nguyen, D.K. ve Kang, S.H. (2016). Global Financial Crisis and Spillover Effects Among The U.S. and BRICS Stock Markets. International Review of Economics and Finance, 42, 257-276.

Mensi, W., Hammoudeh, S. ve Kang, S.H. (2017). Dynamic Linkages Between Developed and BRICS Stock Markets: Portfolio Risk Analysis. Finance Research Letters, 21, 26-33.

Mun, K.C. (2012). The Joint Response of Stock and Foreign Exchange Markets to Macroeconomic Surprises: Using US and Japanese Data. J. Bank. Finance, 36, 383-394.

Nashier, T. (2015). Financial Integration Between BRICS and Developed Stock Markets. International Journal of Business and Management Invention, 4(1), 65-7.

Ono, S. (2011). Oil Price Shocks and Stock Markets in BRICs. European Journal of Comparative Economics, 8(1), 29-45.

Özşahin, Ş. (2017). Yükselen Piyasa Ekonomilerinde Menkul Kıymetler Borsalarının Entegrasyonu: Türkiye ve BRICS Ülkeleri Üzerine Çoklu Yapısal Kırılmalı Eş-bütünleşme Analizi. Yönetim ve Ekonomi, 24(2), 601-619.

Pal, M., Rao, P.M. ve Manimaran, P. (2014) . Multifractal Detrended Cross-Correlation Analysis on Gold, Crude Oil And Foreign Exchange Rate Time Series. Physica A, 416, 452 460 .

Podobnik, B. ve Stanley, H. E. (2008). Detrended Cross-Correlation Analysis: A New Method for Analyzing Two Nonstationary Time Series. Phys. Rev. Lett., 100, 084102.

Podobnik B., Grosse I., Horvatic D., Ilic S., Ivanov P.C. ve Stanley H.E. (2009). Quantifying Cross-Correlations Using Local and Global Detrending Approaches. Eur. Phys.J., 71, 243250.

Polat, M., ve Gemici E. (2017). Analysis of The Relationshıp Between Bist and BRICS Stock Markets in Terms of Portfolio Diversification: Cointegration Analysis with Ardl Boundary Test. Journal of Economics Finance and Accounting, 4(4), 393-403.

Sosa, M. ve Cabello A. (2015). Stock Market Behaviour in the Emerging G-9 (BRICS+4). Revista Latinoamericana de Economia, 46 (181).

Sui, L. ve Sun, L. (2016). Spillover Effects Between Exchange Rates and Stock Prices: Evidence from BRICS Around The Recent Global Financial Crisis. Research in International Business and Finance, 36, 459-471. 
Syriopoulos, T., Makram B. ve Boubaker, A. (2015). Stock Market Volatility Spillovers and Portfolio Hedging: BRICS and The Financial Crisis. International Review of Financial Analysis, $39,7-18$.

Şimşek M. (2016). Borsa İstanbul (BIST) ve BRICS Ülkelerinin Hisse Senedi Piyasalarının İlişkisi Üzerine Bir İnceleme. İnsan ve Toplum Bilimleri Araştırma Dergisi, 5(3),520-536.

Vuran, B. ve Türkay, K. (2017). Emerging Markets Stock Exchange Linkages: Evidence from BRICS and MIST Countries. International Research Journal of Applied Finance, 8(1), 1-11.

Xu, L., Ivanov, P.Ch., Hu, K., Chen, Z., Carbone, A. ve Stanley, H.E. (2005). Quantifying Signals with Power-Law Correlations: A Comparative Study of Detrended Fluctuation Analysis and Detrended Moving Average Techniques. Phys. Rev., 71, 051101.

Yahoo Finance, http://finance.yahoo.com/.

Yarovaya, L., Chi, M. ve Lau, K. (2016). Stock Market Comovements Around The Global Financial Crisis: Evidence from the UK, BRICS and MIST Markets. Research in International Business and Finance, 37, 605-619.

Yıldız, A. ve Aksoy, E. (2014). Morgan Stanley Gelişmekte Olan Borsa Endeksi ile BIST Endeksi Arasındaki Eşbütünleşme İlişkisinin Analiz Edilmesi. Atatürk Üniversitesi İktisadi ve İdari Bilimler Dergisi, 28(2), 1-23.

Zhang, B., Li, X. ve Yu, H. (2013). Finance Has Recent Financial Crisis Changed Permanently The Correlations Between BRICS and Developed Stock Markets?. North American Journal of Economics and Finance, 26, 725- 738.

Zhang, J., Zhang, D., Wang, J. ve Zhang, Y. (2013). Volatilite Spillovers Between Equity and Bond Markets: Evidence From G7 and BRICS, Romanian Journal Of Economic Forecasting XVI(4).

Zhao, H. (2010). Dynamic Relationship Between Exchange Rate and Stock Price: Evidence From China. Res. Int. Bus. Financ., 24(2), 103-112.

\section{Açiklamalar}

${ }^{1}$ Yahoo Finance, http://finance.yahoo.com/. Kullanılan veri kodları: iShares MSCI Turkey ETF (TUR), iShares MSCI Brazil Capped ETF (EWZ), iShares MSCI Russia Capped ETF (ERUS), iShares MSCI India ETF (INDA), iShares MSCI China ETF (MCHI), iShares MSCI South Africa ETF (EZA). 